Chapter 13

\title{
Solid-State Culture for Lignocellulases Production
}

\author{
Ulises Durán Hinojosa, Leticia Soto Vázquez, \\ Isabel de la Luz Membrillo Venegas, \\ Mayola García Rivero, Gabriela Zafra Jiménez, \\ Sergio Esteban Vigueras Carmona and \\ María Aurora Martínez Trujillo
}

Additional information is available at the end of the chapter

http://dx.doi.org/10.5772/64237

\begin{abstract}
Aspergillus sp. and Trametes versicolor solid-state monocultures produced high titers of xylanases and laccases activities (4617 \pm 38 and $2759 \pm 30 \mathrm{U} / \mathrm{g}_{\text {substrater }}$ respectively). Fungal biomass was quantified by estimating the ergosterol content of the mycelium, and by a simple material balance the corresponding residual substrate was obtained. Fungal growth and substrate consumption rates showed different behavior for these monocultures $\left(\mu=0.03\right.$ and $0.11 \mathrm{~h}^{-1} ; r_{s}=-0.04$ and -0.0006 $\mathrm{g}_{\text {substrate }} / \mathrm{h}$, respectively). In this case, xylanases production was directly linked to the growth, while laccases were produced during both growth and maintenance phases. Besides xylanases $(42 \%$ of total Aspergillus enzyme), high titers of cellulases (15\%), amylases (34\%), and invertases ( $9 \%)$, as well as lignin and manganese peroxidases (10 and $24 \%$ of the total Trametes enzyme), were produced on the corresponding monocultures. When both fungi were used in a coculture mode, xylanases and laccases production decreased (around 85 and 70\%), and the proportion of the hydrolases and oxidases changed. This suggested the need for most careful coculture design, in order to produce both enzymatic activities simultaneously even though the enzymatic extracts obtained by mono- or cocultures can be applied in several bioprocesses.
\end{abstract}

Keywords: Aspergillus, coculture, laccases, Trametes versicolor, xylanases

\section{Introduction}

Laccases and xylanases are two of the most important lignocellulases that are employed in several industrial processes. Xylanases (EC 3.2.1.8) are responsible for degrading the xylan, a 
major polysaccharide in several cereals cell wall, to its constituent monomers. These enzymes are mostly used in textile, pulp and paper, bread making and feed industries, and the production of juice and fruit extracts [1,2]. Moreover, laccases (EC 1.10.3.2) are multicopper enzymes that catalyze the oxidation of a wide variety of substrates such as mono-, di- and polyphenols, aminophenols, methoxyphenols, aromatic amines, and ascorbic acid. They have several industrial uses: they degrade toxic fungal metabolites and phenolic compounds and also are used in the design of biosensors, the detection of phenols in wastewaters, in the development of biofuel cells, during bleaching and delignification processes in the pulp and paper industry, and for the production of novel paper products [3]. Together, xylanases and laccases can act for boosting bleaching process of several kinds of pulps, generating a cleaner process in which the use of the hazardous chemicals may be considerably reduced $[4,5]$. These enzymes can be produced mainly by fungus, either in submerged or in solid-state cultures. The former is the most widely used as it provides a good control of operational parameters, high productivity and easy downstream processing, homogeneity of the culture and $\mathrm{pH}$, and better oxygen supply and agitation speed management [6]. However, solid-state culture could be better for producing thiskind of enzymes asitrepresents the conditions that fungus findsinnature during theinvasion of lignocellulosic material. Regarding this, our research group has advanced in optimizing the components of culture media in order to obtain the highest xylanases and laccases activities and yields by Aspergillus sp and Trametes versicolor, respectively [7]. Both enzymatic activities have been evaluated for pulp pretreatment, achieving good results [8,9]. However, the behavior of the corresponding optimized cultures has not been analyzed properly although this information can be used for developing a scalable bioprocess.

On the other hand, the joint use of fungi which produce xylanase or laccase for developing a coculture system may be considered in order to obtain a mixed enzyme preparation, which has both xylanase and laccase activities, for being applied in biopulping and biobleaching processes. This kind of procedure will provide economic advantages because of the reduction in the overall cost of production [10].

Therefore, the objective of this work is to characterize solid-state monocultures with respect to growth, substrate consumption, and xylanases or laccases production and to test a coculture for producing both enzymes at the same solid-state fermentation.

\section{Methodology}

\subsection{Microorganisms}

Trametes versicolor CDBB-H-1051 and Aspergillus sp were used in these experiments. Stock cultures were maintained on malt-extract agar (malt extract $2 \%$, agar $1.8 \%$ ) or PDA slants at $4^{\circ} \mathrm{C}$ with a periodic transfer.

\subsection{Culture conditions for solid-state monocultures}

For developing the corresponding monoculture, each microorganism was cultivated in solidstate fermentation (SSF) using $4 \mathrm{~g}$ of wheat bran and sugar cane bagasse $(1: 1 \mathrm{w} / \mathrm{w})$ as support 
and substrate. For doing this, the support was moistened with water and autoclaved in 250 $\mathrm{mL}$ beakers at $121^{\circ} \mathrm{C}$ for $20 \mathrm{~min}$.

For laccases production monoculture, an appropriate quantity (around $4 \mathrm{~mL}$ ) of Kirk medium was added to maintain the desired moisture level of the support (50\%) for several experimental units. Each beaker was then inoculated with 4 mycelial plugs (50 $\mathrm{mm}$ diameter) taken from the periphery if a T. versicolor colony grown on malt extract agar at $30^{\circ} \mathrm{C}$ for $240 \mathrm{~h}$, withdrawing two experimental units every $24 \mathrm{~h}$ for quantifying growth, residual substrate content and oxidases activities, and employing the analytical techniques described in the following sections.

Kirk basal medium composition (in g/L) was as follows: sodium tartrate, $0.275 ; \mathrm{MgSO}_{4} \cdot 7 \mathrm{H}_{2} \mathrm{O}$, 0.55; $\mathrm{K}_{2} \mathrm{HPO}_{4}, 2.2 ; \mathrm{CaCl}_{2} \cdot 2 \mathrm{H}_{2} \mathrm{O}, 0.145 ;\left(\mathrm{NH}_{4}\right)_{2} \mathrm{SO}_{4}, 0.44 ;$ Glucose, 8.2; $\mathrm{CuSO}_{4} \cdot 5 \mathrm{H}_{2} \mathrm{O}, 0.28$; trace elements, $11 \mathrm{~mL}$ (in $\mathrm{g} / \mathrm{L}$ : $\mathrm{MnSO}_{4} \cdot \mathrm{H}_{2} \mathrm{O}, 0.5 ; \mathrm{NaCl}, 1 ; \mathrm{FeSO}_{4} \cdot 7 \mathrm{H}_{2} \mathrm{O}, 0.1 ; \mathrm{CoCl}_{2} \cdot 6 \mathrm{H}_{2} \mathrm{O}, 0.185$; $\mathrm{ZnSO}_{4} \cdot 7 \mathrm{H}_{2} \mathrm{O}, 0.11 ; \mathrm{Na}_{2} \mathrm{MO}_{4} \cdot 2 \mathrm{H}_{2} \mathrm{O}, 0.011 ; \mathrm{H}_{3} \mathrm{BO}_{3}, 0.011$ ). The $\mathrm{pH}$ of the medium was adjusted at 5.0 using $1 \mathrm{M} \mathrm{HCl}$ before sterilization.

Inoculum from Aspergillus sp was obtained from several 5 day old PDA plates incubated at $37^{\circ} \mathrm{C}$. The spores in the agar surface were gently scraped and blended in $10 \mathrm{~mL}$ sterile saline and used as spore suspension. The spores were enumerated under microscope using a Neubauer chamber. The experimental units used for developing the Aspergillus monocultures for obtaining hydrolytic activities were inoculated using $1 \times 10^{8} \mathrm{spores} / \mathrm{g}_{\text {substrate }}$ and incubated at $37^{\circ} \mathrm{C}$ for $96 \mathrm{~h}$. Two experimental units were taken from incubation every $24 \mathrm{~h}$, for quantifying growth, residual substrate content and hydrolytic activities, employing the analytical techniques described further.

Basal medium composition employed for this monoculture (in $\mathrm{g} / \mathrm{L}$ ) was as follows: $\mathrm{K}_{2} \mathrm{HPO}_{4}$, 2; $\mathrm{KH}_{2} \mathrm{PO}_{4}, 2 ;\left(\mathrm{NH}_{4}\right)_{2} \mathrm{SO}_{4}, 5$.

\subsection{Cocultures developing}

For developing the cocultures in solid state, the same support employed for monocultures was used. This was moisturized and sterilized as indicated before. In this case, the support was moisturized with Kirk basal medium, and both inoculums (T. versicolor and Aspergillus sp.) were added, using the same quantities of the corresponding monocultures (see Section 2.2). Several experimental units were subsequently incubated at 30 or $37^{\circ} \mathrm{C}$ for $240 \mathrm{~h}$. In this case oxidative and hydrolytic activities were quantified for each culture after $240 \mathrm{~h}$.

\subsection{Extraction and storage of crude enzymes}

After incubation, $80 \mathrm{~mL}$ of $100 \mathrm{mM}$ sodium acetate buffer $\mathrm{pH} 5$ was added to each experimental unit, homogenizing with a Multi Braun ${ }^{\circledR}$ mixer and a posterior constant agitation in an ice bath. Afterwards, the enzymatic extracts were recovered by centrifugation at $4000 \mathrm{rpm}$ and stored at $4^{\circ} \mathrm{C}$ until analyzed. The solids obtained after centrifugation were used for estimate biomass and residual substrate content, as explained below. 


\subsection{Enzymatic activities quantification}

Laccase (Lac) activity was determined by measuring the increase in $\mathrm{A}_{470}\left(\varepsilon_{470 \mathrm{~nm}}=26,600 \mathrm{M}\right.$ ${ }^{-1} \mathrm{~cm}^{-1}$ ) due to the oxidation of $10 \mathrm{mM}$ guaiacol in $0.1 \mathrm{M} \mathrm{Na}$-acetate buffer (pH 5.0) after incubation with the crude extract at $25^{\circ} \mathrm{C}$ for $10 \mathrm{~min}$. One unit of laccase activity (U) was defined as the amount of enzyme required to oxidize $1 \mu \mathrm{mol}$ of guaiacol per minute of reaction [11].

Xylanolytic (Xyl) activity was assayed by incubating at $45^{\circ} \mathrm{C}$ for $20 \mathrm{~min}$ using the crude enzyme with $1 \%(\mathrm{w} / \mathrm{v})$ xylan dissolved in $100 \mathrm{mM}$ acetate buffer $\mathrm{pH}$ 5.0, and the release of reducing sugars as xylose was monitored at $575 \mathrm{~nm}$ after stopping the reaction by the addition of DNS. The optical density obtained was compared with a $1 \mathrm{~g} / \mathrm{L}$ xylose standard curve. One unit of xylanolytic activity was defined as the enzyme necessary for the release of $1 \mu \mathrm{mol}$ of xylose under the described conditions [12].

Lignin peroxidase (LiP) activity was estimated by incubating at $25^{\circ} \mathrm{C}$ for $20 \mathrm{~min}$ the crude enzyme with $4 \mathrm{mM}$ veratryl alcohol diluted in $100 \mathrm{mM}$ tartrate buffer $\mathrm{pH} 3.5$ and $0.4 \mathrm{mM}$ $\mathrm{H}_{2} \mathrm{O}_{2}$. The formation of veratraldehyde was monitored at $310 \mathrm{~nm}\left(\varepsilon_{310 \mathrm{~nm}}=9.3331 \mathrm{mM}^{-1} \mathrm{~cm}^{-1}\right)$. One unit of lignin peroxidase activity was defined as the enzyme required for oxidize $1 \mu \mathrm{mol}$ of veratryl alcohol per minute of reaction [13].

Manganese peroxidase (MnP) activity was assayed by Incubating at $25^{\circ} \mathrm{C}$ for $5 \mathrm{~min}$ the crude enzyme with $0.1 \mathrm{mM} \mathrm{MnSO}_{4}, 1 \mathrm{mM} \mathrm{H}_{2} \mathrm{O}_{2}$, and $1 \mathrm{mM}$ 2,6-dimethoxyphenol (DMP) as substrate diluted in $0.1 \mathrm{M}$ tartrate buffer $\mathrm{pH} 4.5$, measuring the increase in $\mathrm{A}_{469} \mathrm{~nm}\left(\varepsilon_{469 \mathrm{~nm}}=27,500 \mathrm{mM}\right.$ $\left.{ }^{-1} \mathrm{~cm}^{-1}\right)$. One unit of manganese peroxidase activity (U) was defined as the amount of enzyme required to oxidize one $\mu \mathrm{mol}$ of DMP per minute of reaction [14].

Glucoamylase (Glcamyl) activity was estimated by incubating at $60{ }^{\circ} \mathrm{C}$ for $15 \mathrm{~min}$ the crude enzyme with $1 \%(\mathrm{w} / \mathrm{v})$ starch dissolved in $0.15 \mathrm{M}$ sodium chloride buffer $\mathrm{pH} 5.0$. The released reducing sugars as glucose were monitored at $575 \mathrm{~nm}$ after stopping the reaction by the addition of DNS. The optical density obtained was compared with a $1 \mathrm{~g} / \mathrm{L}$ glucose standard curve. One unit of glucoamylase activity was defined as the enzyme necessary for the release of $1 \mu \mathrm{mol}$ of glucose under the reaction conditions [15].

$\alpha$-Amylase ( $\alpha$-amyl) activity was determined by incubating at $37^{\circ} \mathrm{C}$ for $20 \mathrm{~min}$ the crude enzyme with $1 \%(\mathrm{w} / \mathrm{v})$ starch dissolved in $0.15 \mathrm{M}$ sodium chloride buffer $\mathrm{pH} 5$. The photometric disappearance of starch was quantified after stopping the reaction by the addition of an iodine (I2/IK) mother solution, and the resultant optical density at $580 \mathrm{~nm}$ was registered. One unit of $\alpha$-amylase activity was defined as the enzyme necessary for hydrolyze $0.1 \mathrm{mg}$ of starch [15].

Invertase (Inv) activity was determined by incubating at $30^{\circ} \mathrm{C}$ for $30 \mathrm{~min}$ the crude enzyme with $0.1 \mathrm{M}$ sucrose dissolved in $0.15 \mathrm{M}$ acetate buffer $\mathrm{pH}$ 5.5. The reducing sugars as fructose were quantified after stopping the reaction with DNS. The optical density obtained was compared with a $1 \mathrm{~g} / \mathrm{L}$ glucose standard curve. One unit of invertase activity was described as the enzyme necessary for the release of $1 \mu \mathrm{mol}$ of reducing sugars per minute of reaction [16]. 
Carboxymethyl cellulase (CMCase) activity was quantified By incubating at $50{ }^{\circ} \mathrm{C}$ for $5 \mathrm{~min}$ the crude enzyme with $(1 \% \mathrm{w} / \mathrm{v})$ carboxymethyl cellulase low viscosity in $50 \mathrm{mM}$ citrate buffer ( $\mathrm{pH}$ 5.0). The reducing sugars as glucose were quantified after stopping the reaction with DNS. The optical density obtained was compared with a $1 \mathrm{~g} / \mathrm{L}$ glucose standard curve. One unit of CMCase activity was described as the enzyme necessary for the release of $1 \mu$ mol of reducing sugars per minute of reaction [17].

The total cellulase activity (filter paper activity, FPAse) was assayed by using a $0.5 \times 6 \mathrm{~cm}$ string of filter paper as the substrate. This was incubated using $100 \mathrm{mM}$ acetate buffer (pH 5.0) and the crude enzyme for $5 \mathrm{~min}$ at $45^{\circ} \mathrm{C}$, stopping the reaction with DNS. The optical density obtained was compared with a $1 \mathrm{~g} / \mathrm{L}$ glucose standard curve. One unit of FPAse activity was defined as the amount of enzyme used for the release of $1 \mu \mathrm{mol}$ of glucose under the assayed conditions [18].

\subsection{Biomass quantification}

The quantification of fungal biomass was made after quantifying ergosterol content of the biomass in each sample. For doing this, the solid content of each experimental unit was resuspended in $10 \mathrm{~mL}$ of water by vigorous agitation. From this homogeneous solid suspension, $1 \mathrm{~mL}$ was withdrawn and filtered, to recover the solids. To this, $3 \mathrm{~mL}$ of an alcoholic basic solution $(25 \% \mathrm{w} / \mathrm{v}$ of $\mathrm{KOH}$ dissolved in methanol) was added, boiling the resultant mixture for $5 \mathrm{~h}$. Afterwards, $1 \mathrm{~mL}$ of distilled water and $5 \mathrm{~mL}$ of $n$-heptane were added, for mixing at the vortex for $3 \mathrm{~min}$. The tubes were let to settle until the phase separation (around $1 \mathrm{~h}$ ), for recording the corresponding optical density at $230 \mathrm{~nm}$ (for detecting the presence of 24(28) DHE, an intermediary of ergosterol pathway) and $280 \mathrm{~nm}$ (for detecting the ergosterol presence) of the organic phase. Ergosterol content of the biomass was estimated using the following equation:

$$
\text { Ergosterol }(\%)=\frac{O . D \cdot a t 280 \mathrm{~nm}}{290}-\frac{O . D \cdot a t 230 \mathrm{~nm}}{518}
$$

where 290 and 518 correspond to the molar extinction coefficient $\left(\mathrm{M}^{-1} \mathrm{~cm}^{-1}\right)$ of crystalline ergosterol and 24(28) DHE, respectively. A $10 \mathrm{~g} / \mathrm{L}$ mycelium (Aspergillus sp or T. versicolor) standard curve was developed, for correlate $\mathrm{g} / \mathrm{L}$ of biomass with ergosterol $\%$. In fact, the calculated ergosterol \% contained on each sample was compared with this curve in order to estimate biomass content [19].

\subsection{Substrate quantification}

The solids obtained from each culture were dried at $60^{\circ} \mathrm{C}$ for $12 \mathrm{~h}$. The biomass content (estimated as explained before) was subtracted to the corresponding dry weight in order to obtain the real substrate content of each sample.

All the experiments were performed in duplicate, and the results are expressed as the mean of these repetitions and the corresponding standard deviation. 


\section{Results and discussion}

\subsection{Behavior of solid-state fermentation monocultures during enzymes production}

On previous work, we optimized the culture media components in order to obtain high xylanase and laccase productions on solid-state fermentation, using Aspergillus sp or $T$. versicolor, respectively [7]. However, these experiments were made at very low volumes, in which only the information of final enzyme production was obtained at 72 or $240 \mathrm{~h}$, respectively. As these enzymes were used successfully for jonote pulp bleaching [8], we decided to increase the volume of the reaction unit, and analyze the behavior of each culture with respect to fungal growth, substrate consumption and xylanase or laccase production. By doing this, we could obtain the basic information to scale up the process for producing both enzymatic activities in large amounts. Also, it could be possible to design an efficient bioprocess in which both enzymatic units can be produced simultaneously.

In this regard, it is worth mentioning that biomass quantification on solid-state cultures is a complicated work. Fungal growth is not easy to quantify because fungus grows as hyphal filaments that cannot be quantified by the usual enumeration techniques, and specifically on cultures in which an insoluble material is used as the only carbon source, complete recovery of fungal biomass from the substrate is very difficult, because the fungal hyphae tend to penetrate into and binds tightly to the solid substrate particles [20]. It is important therefore to have reliable and convenient methods for measuring fungal growth. For this reason, we used the ergosterol content methodology [19] for quantifying biomass evolution along the culture, and employed a simple mass balance for knowing the corresponding residual substrate. Therefore, this is one of the main contributions of the present work.

With respect to monocultures developed with Aspergillus sp., growth seemed to start increasing when the culture was among 20 and $40 \mathrm{~h}$, reaching finally $0.7 \mathrm{~g}$ of mycelium/g of substrate at the end of culture. In this case, the fungus showed an approximate growth rate of $0.03 \mathrm{~h}^{-1}$. Substrate consumption showed a constant rate during the first $60 \mathrm{~h}$, stopping after that. Almost

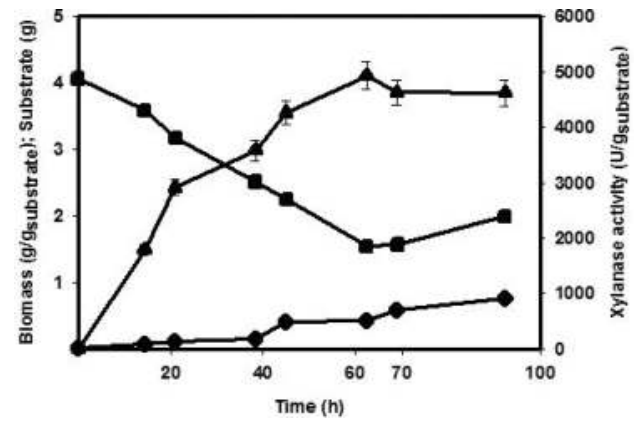

Figure 1. Fungal growth $(\bullet)$, substrate consumption $(\bullet)$, and xylanase production $(\bullet)$ by Aspergillus sp along the solidstate monoculture developed on wheat bran:sugar cane bagasse 1:1 (w/w) as substrate for solid-state fermentation, incubated at $37^{\circ} \mathrm{C}$ for $96 \mathrm{~h}$. 
$2.5 \mathrm{~g}$ of substrate seems to have been consumed during the culture, at a consumption rate of $-0.04 \mathrm{~g}_{\text {substrate }} / \mathrm{h}$. With respect to xylanases production, this started with the same trend as that of fungal growth, and increased constantly, although when the growth stopped xylanolytic activity decreased slightly (Figure 1).

With respect to monocultures developed with T. versicolor for laccase production (Figure 2), it can be seen that in this case there was an adaptation phase of around $50 \mathrm{~h}$, afterwards the fungus started to grow. In this case, it was obtained about $0.6 \mathrm{~g}_{\text {mycelium }} / \mathrm{g}_{\text {substrater }}$ with a constant specific growth rate of $0.11 \mathrm{~h}^{-1}$. However, substrate consumption was really slow $\left(r_{s}=-0.0006\right.$ $\mathrm{g}_{\text {substrate }}(\mathrm{h})$, and the fungi only consumed approximately $1.5 \mathrm{~g}$ along the culture, which represents $40 \%$ of the initial substrate. Laccase production and growth started together, increasing at constant rate, but the enzyme production remained even when biomass stopped growing.

Several studies developed on liquid or submerged fermentation have reported that laccases production has a secondary metabolite behavior; it means the activity is produced mainly during the secondary metabolism [21]. On solid-state culture, this relationship is not well known due to the difficulty of quantifying accurately the total biomass grown in the substrate along the culture. However, other studies in which fungal biomass has been quantified by indirect methods, like that used in the present work, have shown that laccases production is growth related, as happened for laccases produced by Streptomyces psammoticus on rice straw [22]. And those results are in accordance with the T. versicolor profile obtained in the present work.

The titers obtained on each monoculture for xylanases and laccase activities were high. These results show that solid-state culture is a good alternative for producing high oxidative or hydrolytic activities, in order to employ them for several industrial bioprocesses. At this respect, the results obtained in the present work would represent one basis for developing this process on a full- scale. Thereby, for further characterization of the monocultures, in the next section the production profiles of other oxidative or hydrolytic activities obtained were analyzed.

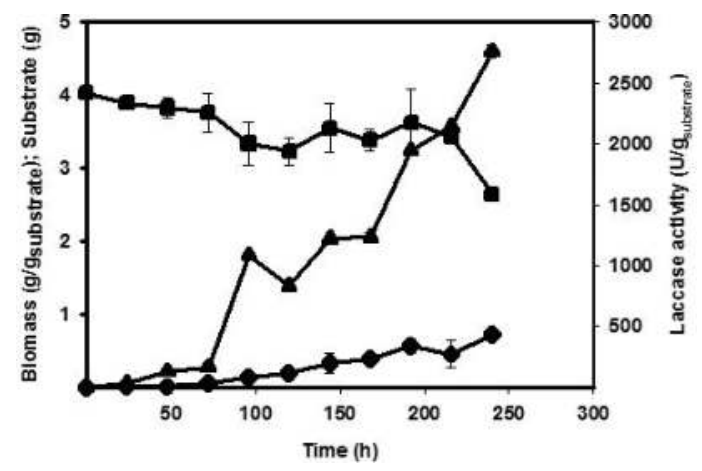

Figure 2. Fungal growth $(\star)$, substrate consumption $(\bullet)$, and laccase production $(\star)$ by T. versicolor in monoculture developed on wheat bran:sugar cane bagasse $1: 1(\mathrm{w} / \mathrm{w})$ as support/substrate for solid-state fermentation, incubated at $37^{\circ} \mathrm{C}$ for $96 \mathrm{~h}$. 


\subsection{Enzymatic profiles of crude enzymes}

Total enzyme production obtained along Aspergillus sp. and T. versicolor solid-state monocultures was determined by quantifying different activities: xylanases, oxido-reductases and cellulases, since it is known that these enzymatic families are involved in invasion of lignocellulosic material [23]. Furthermore, due to wheat bran and sugar cane bagasse composition [24], amylase and invertase activities were also measured.

Along Aspergillus monoculture, xylanolytic activity was predominant; a peak of this activity was reached after $60 \mathrm{~h}$, followed by a constant level until the end of culture. However, another hydrolases were quantified: cellulases and invertases had maximum titers during the first 20 $\mathrm{h}$, after that their levels remained below $1000 \mathrm{U} / \mathrm{g}$ for FPase and $500 \mathrm{U} / \mathrm{g}$ for CMCase, while amylases reached their maximum levels after $48 \mathrm{~h}$ of cultivation, and these activities were kept until the end of the culture. In this monoculture, no oxidase activities were obtained.

With respect to oxidases, during the first $72 \mathrm{~h}$ of monocultures developed with $T$. versicolor, $\mathrm{LiP}$ and $\mathrm{MnP}$ activities were predominant; from this moment, laccase activity increased continuously to reach a peak around $2700 \mathrm{U} / \mathrm{g}$ at the end of process. This activity was almost five times higher than lignin and manganese peroxidases. After $100 \mathrm{~h}$ of cultivation, LiP and $\mathrm{MnP}$ activities stayed at a level around 250 and $800 \mathrm{U} / \mathrm{g}$, respectively. In this T. versicolor monoculture none hydrolytic activity was detected. Table 1 concentrates final titers of all hydrolase and oxidase activities obtained on each of both monocultures.

\begin{tabular}{lll}
\hline Enzymatic activities (U/gs) & Trametes versicolor & Aspergillus sp \\
\hline Laccases & $2759 \pm 30$ & $\mathrm{ND}$ \\
LiP & $410 \pm 10$ & $\mathrm{ND}$ \\
$\mathrm{MnP}$ & $996 \pm 2$ & $\mathrm{ND}$ \\
Xylanases & $\mathrm{ND}$ & $4617 \pm 38$ \\
FPAses & $\mathrm{ND}$ & $746 \pm 7$ \\
Carboximetil-celulases & $\mathrm{ND}$ & $829 \pm 34$ \\
Glucoamylases & $\mathrm{ND}$ & $1762 \pm 4$ \\
$\alpha$-amylases & $\mathrm{ND}$ & $1898 \pm 6$ \\
Invertases & $\mathrm{ND}$ & $1023 \pm 73$ \\
\hline
\end{tabular}

ND indicates the enzyme whose activity was not detected in the corresponding monoculture.

Table 1. Oxidases and hydrolase activities produced by monocultures developed by T. versicolor or Aspergillus sp on solid-state monocultures.

Taking into account that enzymatic extracts obtained on solid-state cultures by Aspergillus sp. and T. versicolor had several hydrolytic or oxidative activities, there could be some other uses for them. In this respect, extracts obtained from Aspergillus sp. monoculture could be used for saccharification processes of a number of agro-industrial residues [25], while the extract 
obtained from T. versicolor monoculture can be proved in color removal of some industrial effluents [26].

\subsection{Cocultures for joint production of lignocellulases}

Solid-state cultures showed high productions of either hydrolase or oxidase activities in the corresponding monocultures. Previous work of this group has shown that bleach boosting of kraft [9] and jonote [8] pulp can be improved with the employment of the combined action of xylanases and laccases, produced by solid-state cultures as those described in the present work. So, a greater enzyme production would be desirable in order to have a more efficient bioprocess. At this respect, it has been suggested that the cocultivation of microbes in fermentation can increase the quantity of the desirable components on a cellulose complex [27]. On the other side, some reports have shown that laccases or xylanases production can increase in a coculture mode, as happens with $P$. ostreatus, which increased fivefold its laccase production in a coculture with Trichoderma viride in submerged fermentation [28]. As discussed earlier, it became interesting to probe if a coculture of Aspergillus sp and T. versicolor was feasible for obtaining higher xylanase and laccase activities at the same time considering that both fungi used wheat bran and sugar cane bagasse as substrate. In addition, this coculture strategy would provide economic advantages because of reduction in overall cost production. This is why both fungi were inoculated at the same time in the support and two incubation temperatures were probed: $30^{\circ} \mathrm{C}$ (the best for T. versicolor) and $37^{\circ} \mathrm{C}$ (the best for A. niger), developing independent experiments. Figure 3 shows the enzyme proportions obtained in cocultures developed at 30 or $37^{\circ} \mathrm{C}$ with respect to the control conditions, obtained in the respective monocultures of each fungi.

With respect to hydrolytic activities proportion, it can be seen that while on monocultures xylanase activity was the predominant hydrolytic activity, glucoamylases were in greater proportion for cocultures developed at $30^{\circ} \mathrm{C}$, and $\alpha$-amylases highlighted on cocultures developed at $37^{\circ} \mathrm{C}$ (Figure $3 \mathbf{A}$ ).

Comparing both cocultures, one can see that the highest hydrolytic activities were obtained on that developed at $37^{\circ} \mathrm{C}$, which means that temperature could be affecting seriously the Aspergillus sp. behavior along this culture. On the other hand, invertase and cellulase activity proportions were low on monocultures, but decreased on both cocultures. The diminution of invertase activity production on coculture modes can be due to the presence of glucose in the media, as Kirk medium was used to moisturize the support in these experiments, and this mineral medium contains glucose. A similar diminution on invertase activity production due to glucose presence in solid-state fermentation was reported previously for A. ochraceus in similar culture conditions, which employed wheat bran or sugar cane bagasse as substrates [29].

Laccase activities decreased on both cocultures with respect to those values obtained on monocultures. This behavior could be considered unusual, because in general the coculture strategy is used in order to increase these activities. In fact, the addition of soil microorganisms to white rot fungi cultures has increased laccase and other oxidases production [30]. In this case, the diminution on laccase activity can be explained from different points of view. First of 
all, in the present study both fungi were inoculated at the same time to the support. The decrease in oxidases and hydrolases production could be provoked by problems in fungal growth, considering the differences in specific growth rate of each fungal species. This is because mineral medium used in these cocultures contained glucose, and it has been reported as laccase inductor for T. versicolor [31]. So, even when Aspergillus grows slower in its respective monoculture, in this case it could be consuming the available glucose of the medium faster than $T$. versicolor could, reducing the ability of $T$. versicolor for producing laccases and the another oxidases. However, to probe this hypothesis, some additional experiments would be necessary.
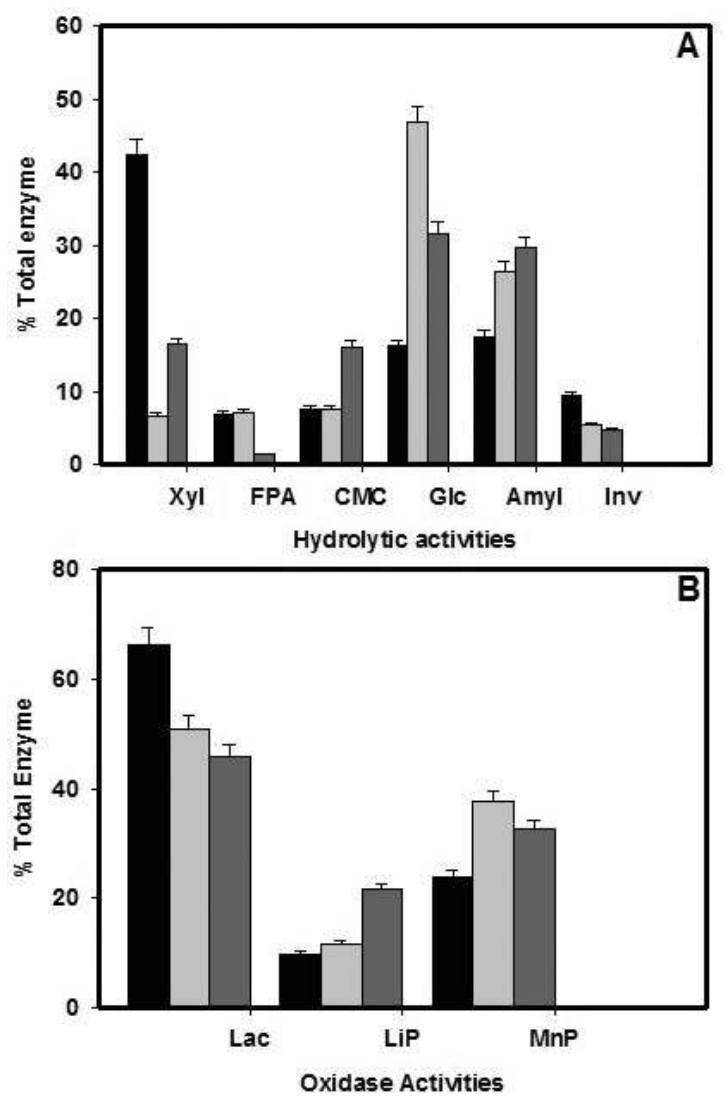

Figure 3. Enzyme proportion of hydrolytic (A) or oxidase (B) activities obtained on monocultures (•), and cocultures developed at $30^{\circ} \mathrm{C}(\square)$ or $37^{\circ} \mathrm{C}(\square)$.

On the other hand, we must remember that enzymes are produced at different rates along the cultures, as described in Section 3.2. In this case, activities analyzed for this experimental phase are those obtained after 10 days, but the enzyme evolution along both cocultures was not 
registered. This is a great limitation for obtaining valid conclusions. It could be possible that one of these enzymes has been increased at any time during the fermentations, but as we did not quantify the enzyme evolution, we could not know if the reported activity was the highest obtained for the corresponding enzyme in this experiment. So, we can only analyze the enzyme activities at the end of the coculture, and these could not be the highest activities obtained in this case.

Finally, even when some hydrolytic or oxidative enzymes decreased on coculture mode, these extracts can be employed on several processes. Agricultural by-products typically vary in their chemical composition and nutritional value, and sometimes are also higher in low-quality fiber, so a specific enzyme complex is required to break it down in order to be used in ruminant feed. Besides, their nutritional value could be increased by biodegradation methods of fiber in the rumen, through efficient delignification [32]. Therefore, the filtrates obtained on both cocultures could be a good alternative for being employed for using agricultural by-products for ruminant feed.

\section{Conclusions}

The indirect technique used for the quantification of fungal biomass content was useful, meaning a great contribution for analyzing solid-state cultures. From this, it could be seen that both fungi have different behaviors along the culture, in which T. versicolor seems to grow faster than Aspergillus sp., and consequently its substrate consumption rate is also higher. However, high xylanases and laccases titers were obtained on the corresponding monocultures. In this case, xylanases production seemed to be growth related, while laccases started to produce since growth phase and continued producing even when fungus stopped growing. In addition, the presence of other hydrolases and oxidases activities showed the potential of the enzymatic extracts for being used in several industrial bioprocesses. Coculture mode caused a decrease in xylanase and laccase production. In this respect, it seems that xylanase production is affected by the incubation temperature, and although Aspergillus sp. grows slower it could be consuming the glucose contained in Kirk mineral medium, delaying the laccases production by $T$. versicolor. Some modification in the inoculation methodology is needed in order to increase the production of these enzymes by coculture. Based on this, we can conclude that solid-state fermentation, independent or as coculture, could be a promising green biotechnology for producing several lignocellulosic enzymes from agricultural residues that can be used for different industrial applications at a lower cost.

\section{Acknowledgements}

LSV acknowledges CONACyT for the scholarship 551418. The authors acknowledge Instituto de Ingeniería, from Universidad Nacional Autónoma de México, Tecnológico de Estudios Superiores de Ecatepec and PRODEP, for the economic funding. 


\section{Author details}

Ulises Durán Hinojosa ${ }^{\sharp 1,}$, Leticia Soto Vázquez ${ }^{\sharp 2,}$, Isabel de la Luz Membrillo Venegas², Mayola García Rivero ${ }^{2}$, Gabriela Zafra Jiménez², Sergio Esteban Vigueras Carmona ${ }^{2}$ and María Aurora Martínez Trujillo ${ }^{2^{*}}$

*Address all correspondence to: amartinezt@tese.edu.mx

1 Coordination of Environmental Engineering, Institute of Engineering, National Autonomous University of Mexico, Ciudad Universitaria, México D.F

2 Division of Chemical Engineering and Biochemistry, Tecnológico de Estudios Superiores de Ecatepec. Avenida Tecnológico esq. Av. Carlos Hank González, Ecatepec, México

\# Both authors contributed equally to this work.

\section{References}

[1] Jin N, Ma S, Liu Y, Yi X, He R, Xu H, Qiao DR, Cao Y. Thermophilic xylanase production by Aspergillus niger in solid state fermentation using wheat straw and corn cob. African Journal of Microbiology Research 2012;6(10):2387-2390. doi: 10.5897/ AJMR11.1433

[2] Mohamed SA, Al-Malki AL, Khan JA, Kabli SA, Al-Garni SM. Solid state production of polygalacturonase and xylanase by Trichoderma species using cantaloupe and watermelon rinds. Journal of Microbiology. 2013;51(5):605-611. doi: 10.1007/ s12275-013-3016-x

[3] Fernández-Fernández M, Sanromán Má, Moldes D. Recent developments and applications of immobilized laccase. Biotechnology Advances. 2013;31(8):1808-1825. doi: 10.1016/j.biotechadv.2012.02.013

[4] Record E, Asther M, Sigoillot C, Pages S, Punt PJ, Delattre M, Haon M, Van den Hondel CA, Sigoillot JC, Lesage-Meessen L, Asther M. Overproduction of the Aspergillus niger feruloyl esterase for pulp bleaching application. Applied Microbiology and Biotechnology. 2003;62(4):349-355. doi: 10.1007/s00253-003-1325-4

[5] Kapoor M, Kapoor RK, Kuhad RC. Differential and synergistic effects of xylanase and laccase mediator system (LMS) in bleaching of soda and waste pulps. Journal of Applied Microbiology. 2007;103(2):305-317. doi: 10.1111/j.1365-2672.2006.03251.x

[6] Xu P, Ding ZY, Qian Z, Zhao CX, Zhang KC. Improved production of mycelial biomass and ganoderic acid by submerged culture of Ganoderma lucidum SB97 using complex media. Enzyme and Microbial Technology. 2008;42(4):325-331. doi: 10.1016/j.enzmictec. 2007.10.016 
[7] Domínguez-Morales D. Optimización de la producción de xilanasas y lacasas fúngicas mediante el empleo de la Metodología de Superficie de Respuesta [Thesis]. Tecnológico de Estudios Superiores de Ecatepec; 2013.

[8] Licona-Soto S.R. Bioproceso integrado para el tratamiento biológico de la pulpa de jonote [thesis]. Tecnológico de Estudios Superiores de Ecatepec; 2014.

[9] García-Rivero M, Membrillo-Venegas I, Vigueras-Carmona SE, Zafra-Jiménez G, Zárate-Segura PB, Martínez-Trujillo MA. Enzymatic pretreatment to enhance chemical bleaching of a kraft pulp. Revista Mexicana de Ingeniería Química. 2015;14(2):335-345.

[10] Dwivedi P, Vivekanand V, Pareek N, Sharma A, Singh RP. Co-cultivation of mutant Penicillium oxalicum SAU E-3.510 and Pleurotus ostreatus for simultaneous biosynthesis of xylanase and laccase under solid-state fermentation. New biotechnology. 2011;28(6): 616-626. doi: 10.1016/j.nbt.2011.05.006

[11] Bertrand B, Martínez-Morales F, Tinoco-Valencia R, Rojas S, Acosta-Urdapilleta L, Trejo-Hernández MR. Biochemical and molecular characterization of laccase isoforms produced by the white-rot fungus Trametes versicolor under submerged culture conditions. Journal of Molecular Catalysis B: Enzymatic. 2015;122:339-347.

[12] Membrillo Venegas I, Fuentes-Hernández J, García-Rivero M, Martínez-Trujillo A. Characteristics of Aspergillus niger xylanases produced on rice husk and wheat bran in submerged culture and solid?state fermentation for an applicability proposal. International Journal of Food Science and Technology. 2013;48(9):1798-1807. doi: 10.1111/ijfs. 12153

[13] Jung H, Xu F, Li K. Purification and characterization of laccase from wood-degrading fungus Trichophyton rubrum LKY-7. Enzyme and Microbial Technology. 2002;30(2):161168. doi: 10.1016/S0141-0229(01)00485-9

[14] Palma C, Martınez AT, Lema JM, Martınez MJ. Different fungal manganeseoxidizing peroxidases: a comparison between Bjerkandera sp. and Phanerochaete chrysosporium. Journal of Biotechnology. 2000;77(2):235-245. doi: 10.1016/ S0168-1656(99)00218-7

[15] Matute L, Bertsch A, Díaz I. Evaluación de la actividad amilolítica de Aspergillus niger ANM-1 en fermentaciones en estado sólido y sumergido para la obtención y caracterización de aditivos enzimáticos. Revista de la Facultad de Agronomía (UCV). 2011;38(1): 9-17.

[16] Romero-Gómez SJ, Augur C, Viniegra-González G. Invertase production by Aspergillus niger in submerged and solid-state fermentation. Biotechnology Letters. 2000;22(15): 1255-1258. doi: 10.1023/A:1005659217932

[17] Miller GL, Blum R, Glennon WE, Burton AL. Measurement of carboxymethylcellulase activity. Analytical Biochemistry. 1960;1(2):127-132. doi: 10.1016/0003-2697(60)90004-X 
[18] Ponce-Noyola T, De la Torre M. Isolation of a high-specific-growth-rate mutant of Cellulomonas flavigena on sugar cane bagasse. Applied Microbiology and Biotechnology. 1995;42(5):709-712. doi: 10.1007/BF00171949

[19] Bhosle SR, Sandhya G, Sonawane HB, Vaidya JG. Ergosterol content of several wood decaying fungi using a modified method. International Journal of Pharmacy and Life Sciences. International Journal of Pharmacy and Life Science (IJPLS). 2011;2(7):916-918.

[20] Abd-Aziz S, Hung GS, Hassan MA, Karim MI, Samat N. Indirect method for quantification of cell biomass during solid-state fermentation of palm kernel cake based on protein content. Asian Journal of Scientific Research 2008;1(4):385-393.

[21] Brijwani K, Rigdon A, Vadlani PV. Fungal laccases: production, function, and applications in food processing. Enzyme Research. 2010 Sep 21;2010. http://dx.doi.org/ $10.4061 / 2010 / 149748$

[22] Niladevi KN, Sukumaran RK, Prema P. Utilization of rice straw for laccase production by Streptomyces psammoticus in solid-state fermentation. Journal of Industrial Microbiology and Biotechnology. 2007;34(10):665-674. doi: 10.1007/s10295-007-0239-z

[23] Hasunuma T, Okazaki F, Okai N, Hara KY, Ishii J, Kondo A. A review of enzymes and microbes for lignocellulosic biorefinery and the possibility of their application to consolidated bioprocessing technology. Bioresource Technology. 2013;135:513-522. doi: 10.1016/j.biortech.2012.10.047

[24] Veana F, Martínez-Hernández JL, Aguilar CN, Rodríguez-Herrera R, Michelena G. Utilization of molasses and sugar cane bagasse for production of fungal invertase in solid state fermentation using Aspergillus niger GH1. Brazilian Journal of Microbiology. 2014;45(2):373-377. http://dx.doi.org/10.1590/S1517-83822014000200002

[25] Mostafa FA, Ahmed SA, Helmy WA. Enzymatic saccharification of pretreated lemon peels for fermentable sugar production. Journal of Applied Sciences Research. 2013;9(3):2301-2310.

[26] Zeng X, Cai Y, Liao X, Zeng X, Li W, Zhang D. Decolorization of synthetic dyes by crude laccase from a newly isolated Trametes trogii strain cultivated on solid agro-industrial residue. Journal of Hazardous Materials. 2011;187(1):517-525. doi: 10.1016/j.jhazmat. 2011.01.068

[27] Kaushal R, Sharma N, Tandon D. Cellulase and xylanase production by co-culture of Aspergillus niger and Fusarium oxysporum utilizing forest waste. Turkish Journal of Biochemistry/Turk Biyokimya Dergisi. 2012;37(1).

[28] Flores C, Casasanero R, Trejo-Hernández MR, Galindo E, Serrano-Carreón L. Production of laccases by Pleurotus ostreatus in submerged fermentation in co?culture with Trichoderma viride. Journal of Applied Microbiology. 2010;108(3):810-817. doi: 10.1111/j.1365-2672.2009.04493.x

[29] Alegre AC, Polizeli MD, Terenzi HF, Jorge JA, Guimarães LH. Production of thermostable invertases by Aspergillus caespitosus under submerged or solid state fermentation 
using agroindustrial residues as carbon source. Brazilian Journal of Microbiology. 2009;40(3):612-622. http://dx.doi.org/10.1590/S1517-83822009000300025

[30] Chan Cupul W, Heredia Abarca G, Martínez Carrera D, Rodríguez Vázquez R. Enhancement of ligninolytic enzyme activities in a Trametes maxima-Paecilomyces carneus co-culture: key factors revealed after screening using a Plackett-Burman experimental design. Electronic Journal of Biotechnology. 2014;17(3):114-121. http://dx.doi.org/ 10.1016/j.ejbt.2014.04.007

[31] Piscitelli A, Giardina P, Lettera V, Pezzella C, Sannia G, Faraco V. Induction and transcriptional regulation of laccases in fungi. Current Genomics. 2011;12(2):104-112. doi: http://dx.doi.org/10.2174/138920211795564331

[32] Graminha EB, Goncalves AZ, Pirota RD, Balsalobre MA, Da Silva R, Gomes E. Enzyme production by solid-state fermentation: application to animal nutrition. Animal Feed Science and Technology. 2008;144(1):1-22. doi: 10.1016/j.anifeedsci.2007.09.029 
